\title{
Ocular pathology of the Majewski syndrome
}

\author{
JEREMY CHESS AND DANIEL M. ALBERT \\ From Harvard Medical School, Massachusetts Eye and Ear Infirmary, 243 Charles Street, Boston, \\ MA 02114, USA
}

SUMMARY A case report with ocular histopathological findings of the Majewski form of short rib polydactyly is presented. The findings included cataract and optic atrophy. The systemic features of this syndrome and the ophthalmic findings are discussed in relation to the Meckel syndrome and trisomy 13 , from which it must be differentiated.

The association of lethal neonatal dwarfism, narrow thorax, and polydactyly is well established in the older literature particularly from the syndromes described by Jeune and Ellis-Van Creveld. ${ }^{1-4}$ There has been renewed interest in this subject and the classification of short rib polydactyly since Majewski et al. described the features of a lethal congenital syndrome characterised by short ribs and limbs, polysyndactyly, median cleft lip, and anomalies of the epiglottis, visceral organs and genitalia. ${ }^{5}$ Subsequent recognition of clinical and radiological differences became apparent as additional cases were studied and gave rise to the reclassification of short rib polydactyly (SRP) to include type I of Majewski and type II of Saldino-Noonan. ${ }^{6}$ Additional reports have demonstrated other variants of this condition, several of which may also be distinct forms. ${ }^{7-16}$

Necropsy reports have been conspicuous for the absence of information on the ophthalmic findings in these cases. We present here the ocular histopathological findings in the Majewski type of SRP and discuss the differential diagnosis and clinicopathological features of this disease group. Heightened awareness of neonatal dwarfism syndromes may lead to the gathering of more information on the ophthalmic aspects of SRP.

\section{Case report}

A $3250 \mathrm{~g}$ male was the product of a full-term gestation. The family history was negative for known congenital abnormalities. Parental consanguinity was denied. The mother was gravida 2, para 1, and apart from a

Correspondence to Professor Daniel M. Albert, MD. Department of Ophthalmology, Massachusetts Eye and Ear Infirmary, 243 Charles Street, Boston, MA 02114, USA. first trimester respiratory infection had had a normal pregnancy. She had taken no medication except for an occasional aspirin. There was a normal, spontaneous vaginal delivery. The Apgar score was 7 at one minute and 8 at 5 minutes. Multiple congenital abnormalities and mild respiratory distress were noted, and the baby was placed in special care facilities.

At birth the baby's weight, length, and head circumference were all in the 50th percentile. There was a midline partial cleft lip with a highly arched but intact palate. The chest circumference was small ( 28 $\mathrm{cm}$ ) and the extremities were short, particularly in their lower third. The interphalangeal creases of each fifth finger were almost superimposed. Bilateral preaxial hexadactyly of the feet was present with syndactylous duplication of the big toes. Direct ophthalmoscopic examination of the fundi did not reveal abnormalities. Physical examination of the heart, abdomen, genitalia, and neurological system was normal. The karyotype was $46 \mathrm{XY}$ and showed normal Giemsa banding.

Oxygen therapy stabilised the respiratory distress to the extent that room air was tolerated with tachypnoea (80-100/minute). Tube feedings were required. Laboratory tests including complete blood count, urine analysis, blood cultures, blood urea nitrogen (BUN), and electrolytes were normal. Bilirubin was $1.3 \mathrm{mg} / \mathrm{dl}$ direct and 3.0 total (22 and 51 $\mu \mathrm{mol} / \mathrm{l})$.

Radiological examination at 2 days of age revealed very short ribs involving all 12 pairs with a resultant narrow thorax. In the lower part the lateral rib cage was concave rather than convex. Sternal maturation was advanced, the skull was normal, and the mandible was V-shaped. Other major skeletal 




Fig. 1 Neonate with short rib polydactyly syndrome.

anomalies included excessively short tibias with medial bowing and preaxial hexadactyly of both feet (Fig. 1).

The child was discharged from the hospital after 17 days. There was failure to thrive despite continued tube feeding and death ensued at 8 weeks of age.

\section{NECROPSY FINDINGS}

The multiple congenital abnormalities as described above were confirmed. Alveolar haemorrhages in the lungs and right cardiac ventricular dilatation were present. There were no additional congenital abnormalities of the internal organs. Histopathological study of the brain revealed anoxic and metabolic encephalopathy, acute and chronic, and very minor cerebellar dysgenesis. Additional details of the clinical history, radiographic findings, and necropsy may be found in the initial report on this patient by Bidot-Lopez et al. ${ }^{11}$

Gross and microscopic findings for the right and left eyes were essentially the same.

Gross examination of right eye. The right globe measured $19 \times 20 \times 16 \mathrm{~mm}$ with $5 \mathrm{~mm}$ of optic nerve attached. The pupil measured $3 \mathrm{~mm}$. The sclera had a bluish hue and the globe transilluminated well. The cornea was somewhat distorted. The globe was sectioned in the horizontal plane. The anterior chamber and angle, iris, and ciliary body appeared to be within normal limits. The lens appeared yellow. The vitreous was slightly cloudy. The retina, choroid, disc, and macula all appeared within normal limits.

Microscopic findings. The corneal epithelium was within normal limits. The stroma was slightly thickened and hypercellular but within normal limits for age. Descemet's membrane and the endothelium were within normal limits. The anterior chamber was formed and the angle structures were well differentiated. There was vacuolation of the iris (Fig. 2) pigment epithelium and increased cellularity of the stroma, normal for that age. The ciliary body was unremarkable. The lens revealed early nuclear sclerosis, and there was posterior displacement of the epithelial bow. There was bladder cell degeneration of the lens cortex. Remains of the vitreous were adherent to the peripheral retina and ciliary body.

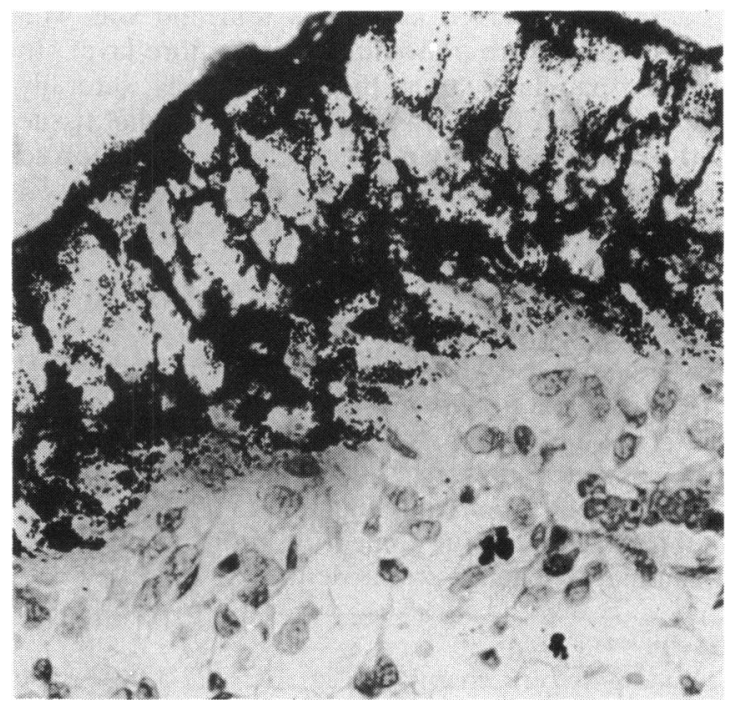

Fig. 2 Vacuolisation of iris pigment epithelium. (Haematoxylin and eosin, $\times 300$ ). 


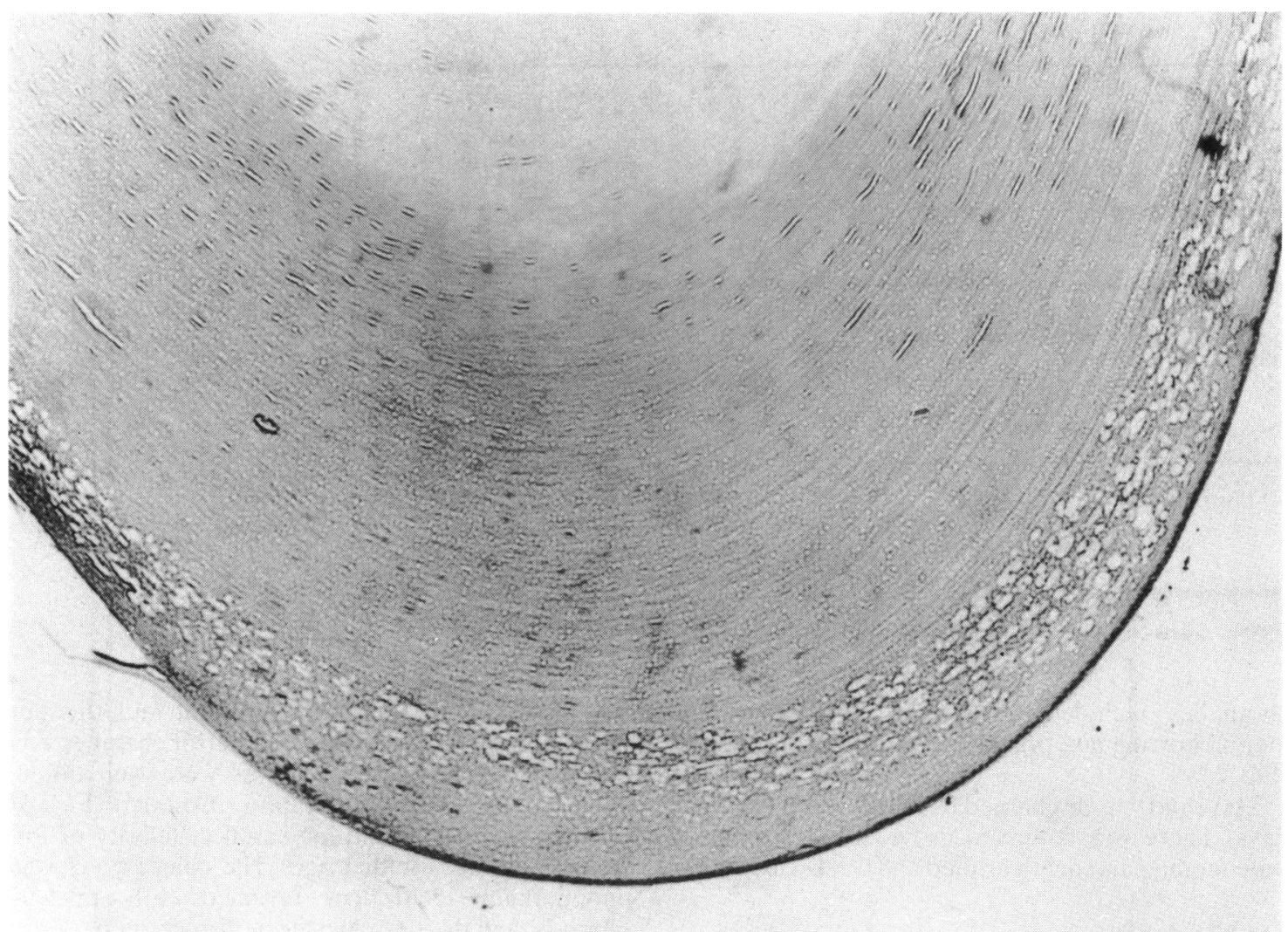

Fig. 3 Lens with cataractous changes and bladder cell degeneration of cortex. (Haematoxylin and eosin, $\times 74$ ).

The retina displayed a Lange's fold and was well differentiated with a prominent nerve fibre layer. In the peripapillary area the retina was laterally displaced, and there was proliferation of glial tissue and extracellular oedematous spaces. The choroid appeared unremarkable. The optic nerve showed glial proliferation and extracellular oedema on the nerve head.

The following special stains were used to study the optic nerve: myelin, Bodian, alcian blue, and luxol fast blue. These stains demonstrated a segmental dropout of the axonal elements and myelin directly posterior to the lamina cribrosa. There were also areas of mucopolysaccharide within the nerve. The optic atrophy appeared segmental, with the more posterior nerve tissue appearing more normal. No inflammatory changes were identified.

DIAGNOSIS

(1) Cataractous changes (Fig. 3). (2) Optic disc oedema (Fig. 4). (3) Segmental optic atrophy with loss of axonal and myelin elements (Fig. 5).

\section{Discussion}

This report emphasises the ophthalmic features of the Majewski type of short rib polydactyly. Previous reports of these syndromes have been concerned primarily with the striking skeletal and visceral anomalies particularly as they relate to the differential diagnosis. While the ophthalmic features are not as striking as other aspects of the condition and not as prominent a feature as in other congenital syndromes such as 13 trisomy or Meckel syndrome, they nevertheless contribute to the pathological description of the syndrome. The present case represents a relatively mild form of the SRP syndrome as shown by the prolonged survival and the lack of visceral findings. It may well be that more severe cases would have a wider range of ocular abnormalities, and it is hoped that ocular histopathological study will be possible in future cases.

The association of neonatal dwarfism with polydactyly, narrow thorax, and other skeletal and visceral anomalies requires consideration of several 


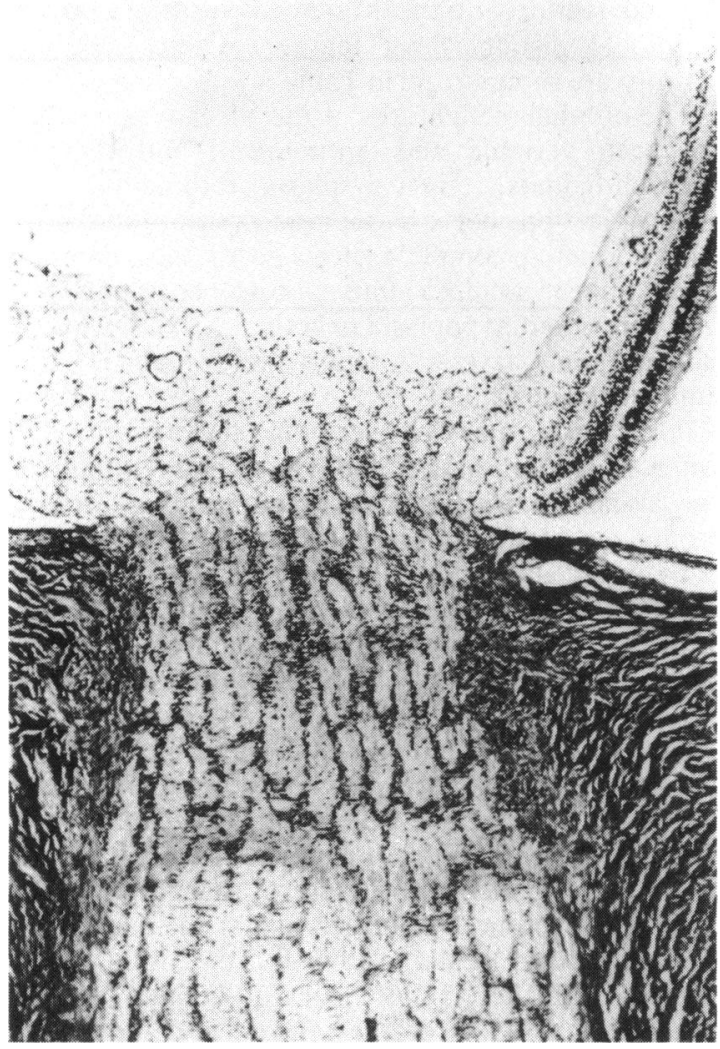

Fig. 4 Optic nerve head oedema and glial proliferation. (Luxol fast blue, $\times 6 \cdot 3$ ). diagnostic entities. The Majewski form of short rib polydactyly is distinguished by the usual presence of a cleft lip or palate, hypoplastic epiglottis, and lung and visceral abnormalities. A comparison of the present case with representative cases of the Majewski form is presented in Table 1 and may indicate a partial penetrance in our case. ${ }^{10}$ Differential features of SRP type II are presented in Table 2 and include the presence of an abnormal pelvis, ragged metaphyses, gastrointestinal and genitourinary atresia, polycystic kidneys, and transposition of the great vessels.

Differential features of chondroectodermal dysplasia are also presented and include the absence of gastrointestinal and genitourinary changes, the absence of cleft palate or lip, the mild involvement of

Table 1 Comparison of cases of SRP I

\begin{tabular}{llll}
\hline & $\begin{array}{l}\text { Present } \\
\text { Case }\end{array}$ & $\begin{array}{l}\text { Majewski et al. } \\
\text { Case l }\end{array}$ & Spranger et al. \\
\hline Birth weight & $3250 \mathrm{~g}$ & $2980 \mathrm{~g}$ & $3500 \mathrm{~g}$ \\
Length & $50 \mathrm{~cm}$ & $44 \mathrm{~cm}$ & $38 \mathrm{~cm}$ \\
Hydropic & & + & + \\
appearance & + & + & + \\
Narrow thorax & + & + & + \\
Polydactyly & + & + & + \\
Short tibia & + & + & + \\
Cleft lip/palate & + & + & + \\
Polycystic kidney & - & - & - \\
Genital anomaly & - & + & - \\
Cardiac anomaly & - & + & + \\
Immediate death & - & + &
\end{tabular}

$+=$ Present.$-=$ Absent

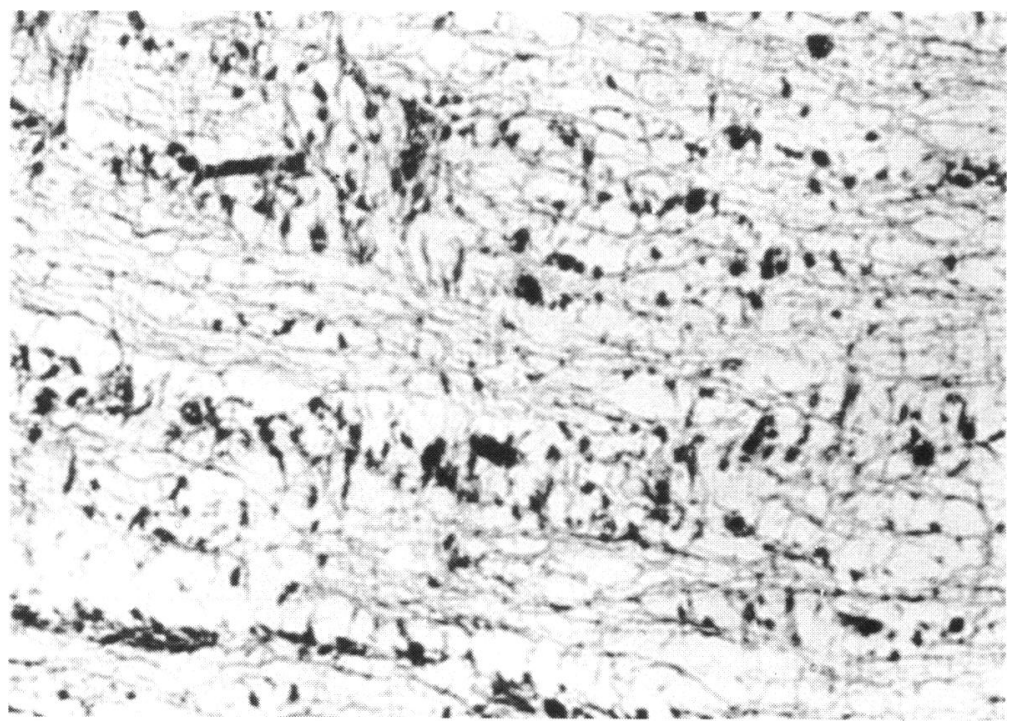

Fig. 5 Optic nerve showing axonal dropout and myelin loss posterior to lamina cribrosa. (Bodian, $\times 40$ ). 
Table 2 Differential features of 3 congenital syndromes

\begin{tabular}{|c|c|c|c|}
\hline & $\begin{array}{l}\text { SRP I } \\
\text { (Majewski) }\end{array}$ & $\begin{array}{l}\text { SRP II } \\
\text { (Saldino- } \\
\text { Noonan) }\end{array}$ & $\begin{array}{l}\text { CED } \\
\text { Chondroectodermal } \\
\text { dysplasia } \\
\text { (Ellis-Van Creveld) }\end{array}$ \\
\hline $\begin{array}{l}\text { GI and GU atresia } \\
\text { Pulmonary }\end{array}$ & - & ++ & - \\
\hline $\begin{array}{l}\text { hypoplasia } \\
\text { Cardiac }\end{array}$ & ++ & ++ & ++ \\
\hline malformation & + & ++ & + \\
\hline $\begin{array}{l}\text { Epiglottic defect } \\
\text { Proximal skeletal }\end{array}$ & ++ & + & - \\
\hline changes & ++ & + & + \\
\hline $\begin{array}{l}\text { Tibial involvement } \\
\text { Deficient }\end{array}$ & ++ & + & + \\
\hline $\begin{array}{l}\text { ossification } \\
\text { Metaphyseal }\end{array}$ & - & ++ & - \\
\hline $\begin{array}{l}\text { dysplasia } \\
\text { Skull, vertebral, }\end{array}$ & - & ++ & - \\
\hline pelvic involvement & - & ++ & + \\
\hline Nail dysplasia & - & - & ++ \\
\hline
\end{tabular}

$+=$ Present.$++=$ Prominent. $-=$ Absent. GI $=$ gastrointestinal $\mathrm{GU}=$ genitourinary.

the proximal long bones, and the smooth metaphyseal margins (Table 2).

Polydactyly may be associated with other congenital syndromes with ophthalmic involvement. The Meckel syndrome is characterised by many severe abnormalities including posterior encephalocele, sloping forehead, microcephaly, cleft lip and palate, polycystic kidneys, and ambiguous genitalia. ${ }^{17} \mathrm{~A}$ normal chromosome karyotype, polydactyly, and neonatal death are features seen in common with the Majewski SRP syndrome. Absence of the prominent skeletal features of the Majewski syndrome is an additional distinguishing feature. These systemic features are summarised in Table 3.

The ophthalmic features of the Meckel syndrome are both variable and pronounced and include microphthalmos, retinal dysplasia, rudimentary iris or aniridia, optic nerve hypoplasia, cryptophthalmos, sclerocornea, incomplete cleavage of the chamber angle, tunica vasculosa lentis, persistence of nuclei in lens fibres, and hypoplasia of retinal nerve fibre and ganglion cell layers. ${ }^{18}$ Ophthalmic features are summarised in Table 4.

Polydactyly may be seen in the trisomy 13 syndrome. Cleft palate and visceral abnormalities may also be present but skeletal abnormalities are not prominent features. The ophthalmic findings are pronounced and include anophthalmia, microphthalmia, colobomata, cataracts, hypertelorism, and small orbits. Deafness, motor seizures, mental retardation, and neonatal death are additional features (Tables 3 and 4). ${ }^{1819}$

The ophthalmic findings in short rib polydactyly are limited in comparison with those seen in the conditions noted above (Table 5). Early cataractous changes and optic nerve atrophy and oedema were found in our patient. The cause of this pathology is uncertain. Absence of intracranial space-occupying lesions or local ocular causes for the optic nerve changes raise the possibility of a toxic neuropathy, particularly in view of the 'anoxic and metabolic encephalopathy' observed on neuropathological examination. A further consideration would be the fact that the severe restrictive respiratory condition of

Table 3 Systemic features of 4 congenital syndromes

\begin{tabular}{|c|c|c|c|c|}
\hline & $\begin{array}{l}\text { Short rib } \\
\text { polydactyly }\end{array}$ & $\begin{array}{l}\text { Meckel } \\
\text { syndrome }\end{array}$ & $\begin{array}{l}13 \\
\text { Trisomy }\end{array}$ & $\begin{array}{l}\text { Chondroectodermal } \\
\text { dysplasia } \\
\text { (Ellis-Van Creveld) }\end{array}$ \\
\hline Occipital encephalocele & - & + & - & - \\
\hline Cleft lip/palate & + & + & + & - \\
\hline Polydactyly & + & + & + & + \\
\hline Perinatal mortality & + & + & + & $+1-$ \\
\hline Normal chromosomes & + & + & - & + \\
\hline Autosomal recessive & + & + & - & + \\
\hline Microcephaly & - & + & + & - \\
\hline Genital anomaly & + & + & - & - \\
\hline Polycystic kidney & + & + & + & - \\
\hline Cardiac defects & + & + & + & + \\
\hline Sloping forehead & - & + & + & - \\
\hline Micrognathia & - & + & + & _- \\
\hline Haemangiomas & - & - & + & - \\
\hline Hernias & - & - & + & _- \\
\hline Narrow thorax & + & _- & - & + \\
\hline Short extremities & + & - & - & + \\
\hline Hypoplastic epiglottis & + & + & - & - \\
\hline Absent olfactory bulbs & + & + & - & - \\
\hline
\end{tabular}

$+=$ Usually present. $-=$ usually absent. 
Table 4 Ophthalmological findings in 3 syndromes

\begin{tabular}{llll}
\hline & $\begin{array}{l}\text { Short rib } \\
\text { polydactyly }\end{array}$ & $\begin{array}{l}\text { Meckel } \\
\text { syndrome }\end{array}$ & 13 Trisomy \\
\hline Microphthalmia & - & + & + \\
Iris anomaly & - & + & + \\
Cataract & + & + & + \\
Retinal dysplasia & - & + & + \\
Optic nerve oedema & + & - & - \\
Optic nerve atrophy & + & - & - \\
Intraocular cartilage & - & - & + \\
Colobomata & - & + & + \\
Persistent pupillary & & & + \\
membrane & + & &
\end{tabular}

$+=$ Usually present. $-=$ usually absent.

Table 5 Summary of ocular findings in SRP

\begin{tabular}{ll}
\hline Present case & 1. Cataract \\
& 2. Optic disc oedema \\
& 3. Optic nerve atrophy \\
Piepkorn et al. ${ }^{8}$ & 4. Lange's fold \\
Cherstvoy et al. $^{10}$ & 1. Ocular hypertelorism \\
\hline
\end{tabular}

the patient for the 8 weeks prior to his death would most likely have caused a hypercapnia and hypoxia, which is a known cause of disc oedema and its sequelae in other clinical entities. The study of the ophthalmic findings in additional cases of the SRP syndromes may increase our understanding of the pathophysiology of this condition.

\section{References}

1 Ellis RWB. Van Creveld S. A syndrome characterized by ecto dermal dysplasia. polydactyly, chondrodysplasia, and congenital morbus cordis. Arch Dis Child 1940; 15: 65-84.
2 Chauss JM. Chondroectodermal dysplasia (Ellis-Van Creveld disease) Radiology 1955; 65: 213-7.

3 Hirokowa K. Suzuki S. Ellis-Van Creveld disease: report of an autopsy case. Acta Pathol Jpn 1967; 17: 139-42.

4 LeMarek B. Passarge E, Dellenbach P, et al. Les formes neonatales, léthales de la dysplasie chondroectodermique. Ann Radio (Paris) 1973; 16: 19-26.

5 Majewski F, Pfeiffer RA, Lenz W, Muller R, Feil G, Seiler R. Polysyndaktylieverkurste Gliedmassen und Genitalfehbildungen Kennzeichen eines selbstandigen syndroms? Eur J Pediatr 1971; 111: $118-38$.

6 Saldino RM, Noonan CD. Severe thoracic dystrophy with striking micromelia, abnormal osseous development including the spine, and multiple visceral anomalies. $A J R$ 1972; 114: 257-63.

7 Spranger J, Grimm B, Weller M, et al. Short rib polydactyly syndromes, types Majewski and Saldino Noonan. Eur J Pediatr 1974; 116: 73-94.

8 Piepkorn M, Karp L, Hickok D, Wiegenstein L, Hall J. A lethal neonatal dwarfing condition with short ribs, polysyndactyly, cranial stenosis, cleft palate, cardiovascular and urogenital anomalies and severe ossification defect. Pathology 1977; 16: 345-50.

9 Motegi T, Kusunoki M, Nishi T. Hamada T, Sato N, Imamura T. Short rib polydactyly syndrome, Majewski type, in two male siblings. Hum Genet 1979; 49: 269-75.

10 Cherstvoy ED. Lurie IW, Shved A, Lazjuk GI, Ostrowskaya TI, Usoex SS. (1980). Difficulties in classification of the short rib polydactyly syndromes. Eur J Pediatr 1980; 133: 57-61.

11 Bidot-Lopez P, Ablow R, Ogden J, Mahoney M. A case of short rib polydactyly. Pediatrics 1978; 61: 427-40.

12 Houston CS, Awen CF. Kent HP. Fatal neonatal dwarfism. J Can Assoc Radiol 1972; 23: 45-61.

13 Naumoff P, Young L, Mazer J, Amortegui A. (1977). Short rib polydactyly syndrome type 3 . Radiology $1977 ; 122$ : 443-7.

14 Lowry R. Wignall N. Saldino-Noonan short rib polydactyly syndrome. Pediatrics 1975; 56: 121-3.

15 Leroy J. Saldino-Noonan short rib polydactyly syndrome. Clin Genet 1978; 13: 127.

16 Kaibara N, Eguchi M, Shibata K, Takagishi K. Short rib polydactyly syndrome type I. Eur J Pediatr 1980; 133: 63-5.

17 MacRae DW, Howard RO, Albert DM. Hsia YE. Ocular manifestations of the Meckel syndrome. Arch Ophthalmol 1972; 88: $106-13$.

18 Hoepner J, Yanoff M. (1972). Ocular anomalies in trisomy 13-15. Am J Ophthalmol 1972; 74: 729-37.

19 Ginsberg J, Bove K. Ocular pathology of trisomy 13. Ann Ophthalmol 1974; 6: 113-22. 